\title{
Attic Philosophy Versus Stoicism: The Problem of the Boundaries of a Citizen's Moral Autonomy (to the Question of Relevance of Classical Theory of Ethics)
}

\author{
Makuhin Petr Gennadyevich, Ph.D. \\ Associate Professor of the Department of History, Philosophy and Social \\ Communications, Omsk State Technical University, Omsk, Russia
}

\begin{abstract}
Topical at the beginning of the third decade of the 21 st century the problem of the degree of moral independence - and therefore responsibility! - of an individual from society/state in the article is considered "through the prism" of the ancient heritage. More precisely, through two prisms: classical Athenian philosophy and the teachings of the Stoics; The duality generated by this, the conflict of assessments of the situation is perceived by us positively, and moreover, it is used as an argument in favor of the need for students (including the technical university) to study the classical ethical heritage. After all, any of the teachings included in the latter contains an element of "relative truth", the assimilation of which will help to approach the "absolute truth" in deciding the question of the boundaries of our own moral autonomy.
\end{abstract}

Key words: morality, personality and polis (society, state), justice, responsibility, history of ethics (Socrates, Plato, Aristotle, Zeno, Seneca, Marcus Aurelius, Cicero).

Introduction. Almost twenty years of experience in teaching ethics (both as an independent course and as an integral part of a philosophy course) at a technical university allows us to state the following. Of all the sections of philosophy, the most problematic in terms of education is precisely this one, which has morality as its subject (this concept, as indicated in the most authoritative Russian profile encyclopedia, fixes the sphere of "higher values and obligations", which summarizes "that slice of human experience, different sides of which are indicated by the words "Good" and "evil", "virtue" and "vice", "right" and "wrong", "duty", "conscience", "justice", etc. "[1, p. 610]). And the point here is not at all in the complexity of ethical concepts: even the most sophisticated of them are easier to understand than the extremely abstract theoretical constructions of ontology, epistemology, philosophy of consciousness. But if the latter in the eyes of conscientious, responsible "techies" students (and only their position we take into account) are valuable, because they obviously help to better understand modern discoveries in the field of physics, cosmology, artificial intelligence, etc., then ethical theories are often perceived by these same students as no more than edification, instruction, requirement. Accordingly, a reaction of rejection occurs. 
Moreover, by referring to ethical literature, students can find confirmation of their assessments! For example, the greatest pre-revolutionary Russian philosopher, V.S. Solovyov, in the preface to his central ethical work "Justification of Good" cited the following metaphor: "This book will not be persuading you to go to Italy or Switzerland when you decided to go to Siberia" [2, p. 70]. And further he explained that such "persuasions" are meaningless: the doctrine of morality is "nothing more than a systematic indicator of the right path of life's wanderings for people and nations... But no statement of moral norms... can make sense for a person who has consciously set himself... a completely different goal" [2, p. 71]. Similarly, the modern Russian philosopher, A. A. Ivin, writes that the problem of the objectivity of moral norms is one of the most difficult in ethics, since "unlike... the laws of the objective world, acting independently of the will and desire of people, all ethical laws are imperatives... Therefore... observation of the facts of the surrounding world can tell us nothing about their truth or falsity" [3, p. 4]. ("Looking ahead", we will object: yes, the statements of the representatives of ethics are imperative in nature, implying their mandatory implementation, but we cannot agree that the observation of society "can tell us nothing about the truth" of moral norms). If we turn to the dominant in European culture of the late 20th century postmodern tradition, we find that it, with its characteristic pathos of singularity, situationality, openness... destroys the enlightenmentrepressive image of ethics prevailing in philosophy, which is reduced to abstract principles and universal definitions" [4, p. 476]. These words belong to A. A. Guseinov, the most authoritative contemporary Russian specialist in the field of the study of morality, and therefore they are very diplomatic. To put it bluntly, the postmodernists tried to destroy traditional ethics, whose venerable age is two and a half thousand years, and to resurrect at the theoretical level (on the ordinary they did not die all this time) the ideas of the ancient sophists about subjectivity and morality, and truth, and beauty as such. (Socrates, in fact, became the "father of ethics" thanks to the uncompromising discussions with the sophists, which his student Plato recorded in his dialogues).

Similar examples could be given more, but the purpose of our article is exactly the opposite: to substantiate the thesis that ethical knowledge, despite all its specificity (which is fixed with varying degrees of radicalism in the above quotations), is objective knowledge. Accordingly, the history of ethical teachings is a process of movement towards absolute truth through a number of relative truths (we use this concept in the Hegelian-Marxist sense: knowledge as a 
whole is correct, but incomplete and inaccurate, containing an element of error). Therefore, the study of this history by students will allow them to formulate (counter) arguments for discussing the most pressing problems of modern society. To prove this to fit into one article, we will make two restrictions: first, from the indicated problems we will choose one, namely the boundaries (or degree) of moral autonomy - and therefore responsibility! - of an individual as a citizen of a certain society/state. Secondly, not being able to consider the whole history of ethics, let us begin, as the Romans said, ab ovo ("from the egg"), consider the opposite versions of the indicated problem, proposed, on the one hand, by Attic philosophers (who, in fact, are the origins of world ethics), and on the other - by the Stoics.

\section{Attic thinkers: the dependence of the moral perfection of the individual on the} harmony of the polis. Attic philosophy is called the heritage of Socrates (470/469-399 BC), Plato (429/427-347 BC) and Aristotle (384-322 BC), "who lived and preached their teachings in Athens (the main city of Attica)" [5, p. 113]. As you know, the first of them did not write anything in principle, and the second, being his student, recorded Socratic conversations (note: "victorious") with various thinkers, and what exactly he "put into the mouth" of his teacher forever will remain a mystery. But then the "joint complex" of ideas of these two "titans of thought" on the question of interest to us is quite obvious. Let us briefly consider it, referring to Plato's "Republic" dialogue: "we first investigate what justice is in states, and then we will examine it in the same way in an individual person" [6, p. 129]. Let us draw the reader's attention to the fact that, firstly, the "state" was designated by the term "polis", that is, "citystate, a special form of social, economic and political organization of society, typical for Ancient Greece" [7, p. 445]. In other words, this term denoted both society and the state as an apparatus for managing it, that is, the "gap" between these two systems in the culture under consideration was minimal, which can be explained by developed democracy. Secondly, the fact that Socrates and Plato begin to consider justice as the most important ethical concept for them not from an individual person, but from a polis. In this regard, they pose the question: "how does justice and injustice arise in states" [6, p. 134]; however, only a fair polis is "genuine, that is, healthy." In other words, justice is the very kind, "thanks to which the state becomes involved in virtue"; [6, p. 204]. Especially important for us is the following conclusion: people "even at the beginning, when they founded the state, they established that this must be done without fail in the name of the whole. ... (which - P.M.) is justice " [6, p. 204]. The words of a prominent Soviet specialist 
in the field of antiquity, S. L. Utchenko, are appropriate here: although Plato linked the genesis of the polis with the need to satisfy the biological and social needs of citizens, at the same time, "the purpose and meaning of the community of people" is much larger. After all, "the policy is intended to embody on a scale more extensive than is available to an individual, the idea of justice" [8, p. 22]. To the question of what exactly is meant by the latter within the framework of Plato's doctrine of the "ideal state", we will briefly answer as follows: the ability of every citizen to work for the common good based on his abilities (as this philosopher himself writes, "devotion to his work among all estates..., and each of them will do what is peculiar to it " [6, pp. 206-207]). Concluding a short consideration of the ideas of Socrates and Plato, we will say that they categorically denied even a "vague hint" that justice "may turn out to be something other than what we recognized it in the state" [6, p. 217].

A student of Plato, Aristotle, formulated the still actual understanding of justice as "proportional equality"; Let us clarify this by referring to his "Nicomachean" and "Eudemian" "ethics". The first of these books says: "There is a middle ground between the extremes of the unjust. This is fair equality." [9, p. 150]. (In other words, the middle between the poles "turns out to be fair equality, which we define as fair" [9, p. 153]). In contrast to the latter, "just equality, without reservations, is ... certainly inequality" [10, p. 718]. The second work points out that justice as "equality of two shares" is "beautiful" precisely because "it means distribution according to merit, and a morally beautiful person is worthy of these benefits" [11, p. 307]. Let us illustrate this with an example from the field of pedagogy: if a teacher gives students who have shown different levels of knowledge the same marks on the exam, this equality is obviously unfair. But inequality will be equally unfair if students are given different grades, which, however, will not correlate with the level of knowledge, but will be exhibited, for example, from personal likes/dislikes.

Next, we will show where, according to Aristotle, ideas about justice and other moral norms arise. They, the philosopher proves, can take place in the consciousness ("soul") of an individual person because they initially arise in the polis. In this regard, we cite his laconic statement from the "Politics": "the concept of justice is associated with the concept of the state, since the law, which serves as a measure of justice, is a regulating norm of political communication" [12, p. 380]. We conclude this block of meaning with a couple of clarifications of Aristotle's position made by domestic researchers. The above-mentioned S. L. Utchenko 
writes that the policy "arises from the needs of life, but, having arisen, exists already to achieve a good life" [8, p. 23], that is, fair, intelligence, etc. According to B.N. Kashnikov, justice "takes place where there are relations between people, objectively requiring measures and proportions" [13, p. 97], that is, just in the policy.

2. Autonomy of ethics in relation to politics in the teachings of the Stoics. As you can see from the dates of birth given in the last paragraph, the three classical Greek philosophers lived in the V-IV centuries BC, in the heyday of polis democracy and, accordingly, social harmony, one of the aspects of which is justice. Of course, this latter cannot be absolutized; the clearest example of its violation is the death sentence to Socrates. However, it is indisputable that the next stage in the development of the polis (which fell, starting from the fourth century BC under Roman influence, and then directly captured by the Roman Empire), forced philosophers to "transfer" responsibility for (a)morality from society to a person. In this regard, we will present the main features of this era, called Hellenism: "the change in the attitude of the Greeks to the monarchy, which began to be perceived as an acceptable form of government; the formation of a new type of Greek culture, to a lesser extent associated with the tradition of the polis" [14, p. 353]. We will place special emphasis on the initial period of Hellenism (almost half a century of "wars of the Diadochi", that is, the heirs of Alexander the Great, IV-III centuries BC), and on the final (three centuries of agony of the Western Roman Empire, the symbolic "death" date which is considered 476).

This allows us to agree with the most authoritative modern Russian specialist in the study of morality, A. A. Guseinov: a fundamental innovation in comparison with Socrates, Plato and Aristotle was that ethics became independent of politics "and the moral perfection of a person was not connected and dependent from the perfection of social life. Philosophy began to play a mediating role between the individual and the virtue played by the polis" [4, p. 472].

This was especially clearly manifested in the ethics of the Stoics: the path to their moral ideal, namely to equanimity, moral steadfastness, "lies through philosophy, knowledge. Where philosophy is, there is a sage. The sage, whose image is most fully developed in Stoic ethics, appears as the embodied virtue"[4, p. 472]. In other words, Stoicism, represented primarily by Zeno (334-262 BC), Seneca (4 BC-65 AD), Marcus Aurelius (121-180 AD), Marcus Tullius Cicero (106-43 BC), along with other schools of Hellenism (cynicism, epicureanism and skepticism) - the essence of "practically oriented philosophy, the purpose of which is to 
substantiate "wisdom" as ethical ideal" [15, p. 640]. Accordingly, ethics as a central part of Stoic philosophy "which had a universal influence on the entire development of ethics from Christianity to Kant, is based on the idea of the autarchy of virtue when combining the concepts of virtue and happiness" [15, p. 641]. (Here it is necessary to clarify that the concept of autarchy, derived from the Greek "self-sufficiency", just implies independence, autonomy, primarily from the field of politics). At the same time, the following paradox must be taken into account: the philosophy of Stoicism is primarily characterized by "rigid doctrines of absolute valor and duty, acceptance ... of fate, combined with the indispensable involvement in an active political life" [16, p. 1036]. This situation can be called paradoxical because fatalism is combined with political activity, which, however, is doomed to failure in advance by Fate as an irresistible force. The question arises: why fight then? Then, the Stoics answer us through two millennia, that "it is better to die worthily than to live unworthily." Note that even such a representative of Stoicism as Emperor Marcus Aurelius, "needed this philosophy as a cure for court life ... with its passing quarrels and ambitions and from constant irritation caused by the baseness of the courtiers" [17, p. 352]. In other words, even formally the most powerful man of the Roman Empire felt that he could not overcome the Fatum hanging over the country.

We will end this block of meaning with indicative arguments of the Cicero which can be called the embodiment of the stoic spirit) about the virtue that we paid special attention to when analyzing the ideas of Attic ethics - namely, about justice. Underlying law, it was understood by him - laconically stated by the Russian researchers of the latter - "as an eternal, unchanging and inalienable property of both nature as a whole and human nature" [18, p. 88]. "Let's give the floor" to Cicero himself: the virtue of our interest "is by nature divided into two parts: to give each his own and the right to revenge. Institutional equity - into three parts. The first is the law, the second is decency, the third is ancient customs" [19, p. 78-79]. As we can see, unlike the classical Greek philosophers, justice as such is derived not from the polis with its "laws", "propriety" and "customs", but from "nature", the cosmos.

Conclusion. Let us pose the question: what advantage do we, "residents of the third decade of the 21 st century", have over people of previous centuries in terms of solving ethical problems? Obviously, neither gadgets, nor computers, nor neural networks are able to help us either with a moral choice or with a moral assessment of someone's (including our own) choice. (Here the words of the French philosopher J. Ellul (1912-1994), an astute critic of technology, 
about the "subjective factor" that distinguishes human knowledge proper from information used by an arbitrarily perfect computer, are appropriate here. It is about the need to "cut" the "Gordian knot" with each act of choice [20, p. 280]; means we are talking about solving problems that involve not just rational processing of initial information, but an appeal to values). Accordingly, our "trump card" in this issue before, for example, the Greeks lies in our knowledge of how they, and the thinkers of subsequent eras, formulated "ross-cutting," universal problems for mankind, and also in an attempt to solve them defended various, including opposite, arguments. Therefore, if we - and we are talking primarily about students! - if we ignore the theoretical development of the ethical heritage, starting from antiquity, then we will lose this advantage. In other words, having "descended" from the scientific (to which we also include philosophy) level of thinking to the ordinary one, we lose this advantage over people of the past, and can only rely on personal, initially limited and subjective experience. Within the framework of the latter, the problem of the boundaries of the moral autonomy of a citizen cannot be adequately solved: only specific examples can be listed as its solution. But after all, everyone knows examples of both the influence of social norms on the individual, and vice versa, the ability of the latter to resist such influence, to act contrary to it. Therefore, the problem stated in the title of our article is doomed to remain unsolved. While acquaintance with the elements of relative truth contained in the teachings of both the Athenian philosophers and the Stoics, allows us to approach absolute truth (although, of course, this is an endless process) in solving, in particular, the question of the degree of moral autonomy of us as citizens of a particular modern society.

\section{References}

1. Apresyan R. G. Moral // New Philosophical Encyclopedia: In 4 volumes. Vol. 2. - M.: Mysl, 2010. P. 610-612.

2. Soloviev V. S. Justification of good. Moscow: Institute of Russian Civilization, Algorithm, 2012. p. 656.

3. Ivin A. A. Axiology. M .: Higher school, 2006. p. 390.

4. Guseinov A. A. Ethics // New philosophical encyclopedia: in 4 volumes. Vol. 4. M.: Mysl, 2010. P. 472-477.

5. Attic philosophy // Philosophical Dictionary: Founded by G. Schmidt. 22nd, new, revised. ed. by G. Shishkoff. Moscow: Republic, 2003. P. 113.

6. Plato. Republic // Plato. Collected works: In 4 volumes. Vol. 3. M.: Mysl, 1994. P. 79-420. 
7. Polis // Dictionary of Antiquity / Compiled by: Irmscher J., Johne R. M. : Progress, 1989. P. 445.

8. Utchenko S. L. Political teachings of ancient Rome. M.: "Nauka", 1977. p. 256

9. Aristotle. Nicomachean ethics // Aristotle. Compositions: In 4 volumes Vol. 4. M.: Mysl, 1983. P. 53-293.

10. Notes // Aristotle. Compositions: In 4 volumes Vol. 4. M.: Mys1, 1983. P. 681-788.

11. Aristotle. Eudemian ethics. Moscow: IP RAS, 2005. p.448

12. Aristotle. Politics // Aristotle. Compositions: In 4 volumes Vol. 4. M.: Mysl, 1983. P. 375644.

13. Kashnikov B. N. The concept of general justice of Aristotle: The experience of reconstruction // Ethical thought. 2001. No. 2. P. 89-117.

14. Ladynin I. A., Ladynin I. A., Nalimova N. A. Hellenism // Great Russian Encyclopedia: In 35 volumes. V. 35. M: Great Russian Encyclopedia, 2017. P. 353-357.

15. Stolyarov A. A. Stoicism // New philosophical encyclopedia: In 4 volumes. Vol. 3. - M.: Mys1, 2010. P. 639-642.

16. The Cambridge History of the Ancient World / ed. by A. L. Bowman [and others]. Volume X. pt. 2. Empire of August 43 BC - AD 69 M .: Ladomir, 2018. p.1439

17. The Cambridge History of the Ancient World / ed. by A. L. Bowman [and others]. Volume H. pt. 1. Empire of August 43 BC - AD 69 M .: Ladomir, 2018. p.1439

18. History of political and legal doctrines: Textbook for universities / total. ed. by Nersesyants V.S. 2nd ed., Revised and corrected. M .: Norma, 2004. p.944

19. Cicero. Topika// Cicero. Aesthetics: Treatises, Speeches. Letters. Moscow: Iskusstvo, 1994. P. 56-81.

20. Ellul J. The technological bluff // The idea of a man: Anthology / Compilation, introductory article: Gurevich P. S. M.: High School, 1995. P. 265-284.

\section{Translation of references list to original language}

\section{Библиографический список}

1. Апресян Р. Г. Мораль // Новая философская энциклопедия : В 4 т. Т. 2. М.: Мысль, 2010. C. 610-612.

2. Соловьев В. С. Оправдание добра. М.: Институт русской цивилизации, Алгоритм, 2012. $656 \mathrm{c}$.

3. Ивин А. А. Аксиология. М.: Высшая школа, 2006. 390 с.

4. Гусейнов А. А. Этика // Новая философская энциклопедия : в 4 т. Т. 4. М. : Мысль, 2010. C. 472-477. 
5. Аттическая философия // Философский словарь: Основан Г. Шмидтом. 22-е, новое, переработ. изд. под ред. Г. Шишкоффа. М.: Республика, 2003. С. 113.

6. Платон. Государство // Платон. Собрание сочинений : В 4 т. Т. 3. М. : Мысль, 1994. С. 79-420.

7. Полис // Словарь античности / Составители: Ирмшер Й., Йоне Р. М. : Прогресс, 1989. C. 445 .

8. Утченко С. Л. Политические учения древнего Рима. М.: «Наука», 1977. 256 с.

9. Аристотель. Никомахова этика // Аристотель. Сочинения : В 4 т. Т. 4. М. : Мысль, 1983. C. 53-293.

10. Примечания // Аристотель. Сочинения : В 4 т. Т. 4. М. : Мысль, 1983. С. 681-788.

11. Аристотель. Евдемова этика. М. : ИФ РАН, 2005. 448 с.

12. Аристотель. Политика // Аристотель. Сочинения : В 4 т. Т. 4. М. : Мысль, 1983. С. $375-$ 644.

13. Кашников Б. Н. Концепция общей справедливости Аристотеля: Опыт реконструкции // Этическая мысль. 2001. № 2. С. 89-117.

14. Ладынин И. А., Ладынин И. А., Налимова Н. А. Эллинизм // Большая российская энциклопедия: В 35 т. Т. 35. М: Большая Российская энциклопедия, 2017. С. 353-357.

15. Столяров А. А. Стоицизм // Новая философская энциклопедия : В 4 т. Т. 3. М. : Мысль, 2010. С. 639-642.

16. Кембриджская история древнего мира / Под. ред. А. Л. Боумэна [и др.]. Том Х. Полутом 2. Империя Августа 43 г. до н.э. - 69 г. н.э. М.: Ладомир, 2018. 1439 с.

17. Кембриджская история древнего мира / Под. ред. А. Л. Боумэна [и др.]. Том Х. Полутом 1. Империя Августа 43 г. до н.э. - 69 г. н.э. М.: Ладомир, 2018. 736 с.

18. История политических и правовых учений: Учебник для вузов / Под общ. ред. В. С. Нерсесянца. 4-е изд., перераб. и доп. М.: Норма, 2004. 944 с.

19. Цицерон. Топика // Цицерон. Эстетика: Трактаты, Речи. Письма. М.: Искусство, 1994. C. 56-81.

20. Эллюль Ж. Технологический блеф // Это человек: Антология / Составление, вступительная статья: П. С. Гуревич. М. : Высшая школа, 1995. С. 265-284. 